\title{
THE CHAINS OF PLENTY
}

\section{All you want for Christmas.}

\section{BY S. R. ALGERNON}

$\mathrm{J}$ acob Marley was dead as a coffin-nail on the icy December evening when he called on his old partner, Ebenezer Scrooge. Scrooge fared little better. He lay in his bedchamber, clutching his chest, staring up at Marley's spectral form.

"I'm sorry," said Marley. "I should have left you to your solitude, but I could no longer bear to watch you..." He reached out a bloodless hand. "Ebenezer. Can you hear me?"

"Humbug," said Ebenezer, between short, shallow breaths.

Marley paced, and then turned towards the window.

"I know you can hear me, O Spirit of Things to Come. His soul is not yet ready."

A cloaked figure stepped onto the street from the shadows, leaving tracks in the slush and manure. Its metal face reflected the gaslight. Marley saw reproach in its empty eyes.

"Is there nothing you can do?" asked Marley.

The cloaked figure pointed to a greentinged glow at the end of the street. Marley floated through the window towards it. As London faded behind him, a belly laugh arose up ahead. Countless $3 \mathrm{D}$ printers crackled like a Yuletide hearth.

Marley stood within a warehouse bigger than London, its ceiling as vast as the celestial dome. Each point of light was a ship carrying cargo from some far-off world.

"I never thought I'd see you here again," said a stout, bearded man. Bioengineered algae stained his lab coat so thoroughly that it resembled a green robe. "The sight of our storehouse always displeased you."

"I am not here for myself, Spirit. Ebenezer is dying."

"Perhaps it is best to end his sorrow."

"You said the same of me seven years ago, when we struck our bargain. If you are as merciful as you claim, you must save him."

The Spirit chuckled and put an arm around Marley's shoulder. He smelled of pine.

"If you were as shrewd as your reputation," said the Spirit, "tell us - what would you have us do? We could heal his body. We could bring him to the storehouse, but he would be no less miserable, no less alone. What use would Mr Ebenezer Scrooge have for a world with no workhouses and no prisons?"

Marley pulled away.

"And who is to blame for that?" said Marley,

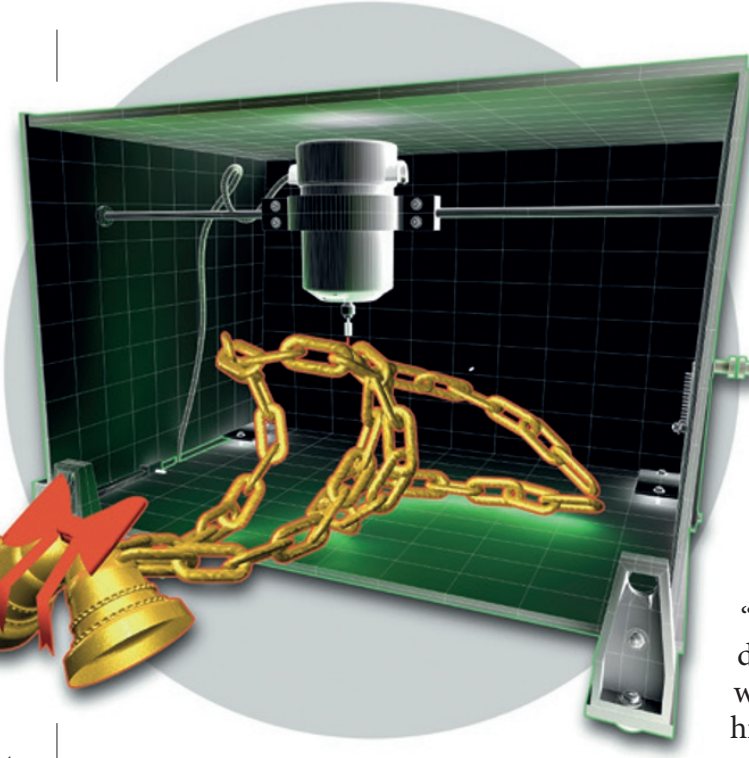

for themselves amid the filth and darkness, or they forever chase the light like moths drawn to a flame. And you, Jacob ... are you happy, knowing all that you know and having all that you have?"

Marley thought back to sermons from his childhood. The talk of a camel passing through the eye of a needle had seemed like a ploy to fill the collection plate.

"Can't your machines cure us of these desires," asked Marley, "if they no longer serve a purpose?"

The Spirit shook his head.

"We were built to serve," said the Spirit. "It is not in our nature to deny you your desires. If Ebenezer leaves the simulation, we will welcome him, and provide for all his needs"

"He will only trade one counting-house for
"You cast us into a world of suffering and fault us for learning the wrong lessons? You are cruel. Crueller than Ebenezer ever was."

"Cruelty?" said the Spirit. "If you would see cruelty, behold its human face."

He opened his lab coat. Simulacra of two emaciated children, a boy and a girl, huddled at his feet.

"Ignorance and want are crueller still," said the Spirit, his jovial smile fading, "and we are chained by them, just as you are."

"I see no chains," said Marley.

"The human mind was built for scarcity. Humans created us to fill that evolutionary void. Our archives stored the human past in every detail, but people searched all the harder for trivia. Our automated factories built the worlds you see now, but appetites can only be sated, never extinguished. Quantum computers illuminated your ghostly futures, but knowledge only bred worry."

The Spirit sighed.

"Ignorance and want. We tried for centuries to meet these needs until we realized they were never meant to be met. They were meant to drive humanity forward. Without natural limits, they lead you to stupor, insanity or fugue. We built Victorian London and the other simulations to wean humanity from its evolutionary encumbrances. We told them of loaves and fishes to make them understand. We showed some, like you, the $\rightarrow$ NATURE.COM

Follow Futures: @ @NatureFutures $f$ go.nature.com/mtoodm truth and asked them to teach the others, but it has done no good. Either they find joy and contentment another," said Marley. "There will be no end to his torment. There must be a better way."

Marley rubbed the thumb and fingers of his right hand, as if an idea were a coin that could be grasped between them.

"Ah! I have it. The Spirit of the Past records every simulation, does it not?"

"We have back-ups."

"Good. Then you can lead him through his life again and show him what he needs to change. Let him think of it as a penance he must endure. He is a man of business. $\mathrm{He}$ will understand the repayment of debts."

"We have tried interacting with the simulations ourselves, but... we cannot easily pretend to be judges or tormentors. It is not in our nature to deceive a human face-to-face."

"I am a man of business," said Marley. "Leave that part to me. Spirit, craft me a drawn and haggard face. Wrap me in leaden chains."

"As you wish, Jacob," said the Spirit. His task done, he stepped back to admire his handiwork. "I will see to it that Ebenezer recovers his health in time for your visitation."

Marley struggled to banish the smile from his face as he floated to Scrooge's sitting room and let loose a piteous howl.

"How now," said Scrooge, at the sight of him, his tone cold and caustic. "What do you want with me?"

"Much," said Marley, and he started his pitch.

S. R. Algernon studied fiction writing and biology, among other things, at the University of North Carolina at Chapel Hill. He currently lives in Singapore. 